\title{
Proceedings on Engineering Sciences
}

\section{INFLUENCE OF OFFICE FACILITIES AND WORK PLACE ENVIRONMENT ON STAFFS' PRODUCTIVITY IN THE UNIVERSITY SYSTEM}

David Ngwoke Mbazor

Keywords:

Office; Facilities; University;

Work environment; Office facilities;

Productivity.

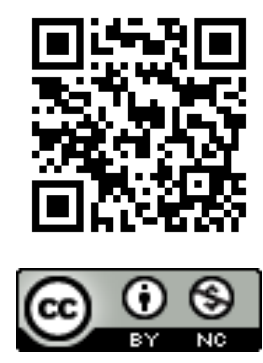

A B S T R A C T

The importance of office facilities and workplace environment in the university system cannot be overemphasized because office facilities help in facilitating work schedules and increase staff's efficiency and productivity. Unfortunately, in many universities in the developing countries such as Nigeria, there are inadequate facilities in the staff offices, and such has resulted in low productivity and has impacted negatively in universities' global ranking. The study assessed the facilities provided in the staff offices at the federal university of technology Akure Nigeria and examined the essential facilities that influence staff productivity. A total of 204 questionnaires were administered to both the academic and non-academic staff members drawn from the eight (8) academic schools that are in the university. 184 of the administered questionnaires were retrieved from the respondents representing $90.2 \%$ and therefore served as the basis for the analysis. A descriptive method of analysis was used to analyze the data. The study revealed that the conditions of fire prevention facilities such as fire extinguisher installed for workers are not functional; the same applies to the toilet facilities. Also, the further revealed that the staffs are very dissatisfied with the condition of conveniences and the state of the sofa in the offices. Finally, the study revealed that the most relevant facilities that influence staff productivity are water, electricity, and Wi-Fi. The study, therefore, recommends that the universities should make adequate provision for water, toilet, electricity, sofa, and fire extinguishers in the staff offices as these have the potential of motivating workers for greater commitment and higher productivity.

(C) 2020 Published by Faculty of Engineering

\section{INTRODUCTION}

University staff or workers spend the majority of their day inside their offices where they discharge their responsibilities, hence the office environment and available facilities are important and should be adequately provided functional to improve a good and healthy working environment for effective service delivery and higher productivity. Denyer (1969), defined an office as a place where clerical operations take place. Office, according to Mike, 2010) is described as a place where vital information on paper is prepared and filed and used for present and future business operations In the view of Kaplan \& Norton (1996), the office is described "as a building in a place of work where information and knowledge is managed, processed and transmitted through document filing and planning, designing, supervising, analyzing, deciding and communicating". 
To effectively coordinate and administer organizational activities, office space or building is of paramount importance.

The availability and functionality of basic facilities in universities is one of the key factors that prospective staff and students consider before choosing to work or study in a particular university. To achieve organizational goals, the human resources component of such an organization must be ably supported by the provision of basic essential office facilities such as office table, airconditioner, ceiling or wall fan, office cabinet, bookshelves, etc.

The primary goal of most universities is a drive towards becoming the best among the comity of universities in academic excellence. To realize this goal, universities invest so much on capital infrastructure and facilities capable of attracting and retaining quality staff and students. Conservatively, it is estimated that university facilities account for $80 \%$ of the total capital assets owned by each university, the same can be said of other organizations. De Been and Beijer (2014) stated that in specifying and designing office environment concept, a range of organizational goals can be employed as the foundational basis. The goals of an organization as identified include "increasing the sharing of knowledge within the organization, cutting facility costs, enhancing the organization's reputation, maximizing productivity, and achieving a more flexible building to cope with future organizational changes".

The work environment (including staff offices) plays an important role in the employees' life. Hence, Noblet (2003) suggested that greater attention should be given by employers in detecting and dealing with the working conditions of their staff. This is necessary because once an employee developed a negative perception of his/her work environment; it sometimes results to stress. Similarly, Griffiths and Cox (1996) observed that "workers who are stressed are likely to be unhealthy, poorly motivated and less productive at work". The study found that workers and by stressed extension people perform below expectations. Staff productivity is directly related to the working conditions which are also directly related to lateness, absenteeism, etc.

The achievement of the organizational goals depends largely on the performances of the employees. Employers of labor are recognizing the fact that personal issues, as well as work- environment issues can influence employee work productivity (Wilkins et al., 2007). Based on the information above, it is the researcher's view that office facilities issue in the workplace can result in low productivity on the part of an employee. This study is conceived to examine the influence of office facilities to staff's productivity at the Federal University of Technology Akure Nigeria.

\section{LITERATURE}

Office facilities are a major investment for all institutions of higher learning all over the world. The value of such investments might reach hundreds of millions of naira or whatever currency traded in a particular country, particularly in the case of staff offices.

Accommodating workers in state of the art offices not only enhance productivity for such special employees but also establishes a moral link and sense of belonging, essential to retain high caliber staff within their institutions (Hassanain et al., 2010). It might have an adverse effect if the quality of the office facilities and the general quality of the office environment is compromised, given that staff's satisfaction and comfort with the office facilities and work environment are directly related to the level of their productivity (Mbazor et al., 2018).

The process of identifying and attracting appropriate talents into the universities requires the recruitment of academic and non-academic staff to attain wider recognition (Calder, 2007). However, choosing appropriate talents alone is not the only factor that earns high recognition and popularity. Hence, Hamid and Hassan (2015) opined that preparing a proper workplace with adequate facilities to support, assist and motivate workers is a crucial factor that cannot be omitted by organizations that aspire to succeed particularly in the 21 st century.

\subsection{Office Environment}

Gerber et al. (1998) identified the office working environment to include the availability of facilities like furniture, equipment, appliances and surrounding temperature. The physical layout of the office environment refers to the arrangement, orderliness, neatness, circulation, organization, convenience, aesthetic and attractiveness of the office environment (Luthans, 1998). Similarly, Schabracq (2003) stated that a decent office and work environment is such that is devoid of distraction such as noise, interference, and other unpleasant situations, sleepily floors, heat, cold, moist, poor lighting, and unpleasant color.

Decent office condition enhances the employees' performance of tasks without unnecessary stress if all facilities are available and at their reach. McConnell (2003) noted that the lack of essential facilities such as heating systems, lighting systems, furniture, space arrangement, and noise situation can cause undue stress for organizational employees. Therefore if the facilities in the office and the general working environment are good - such as adequate water supply, toilet, machines and equipment, standard furniture, temperature condition, etc., it will be easy for the employees to discharge their duties diligently. 
On the other hand, if the office condition is poor - such noisy environment, dirty walls, too hot or cold environment, smelling surrounding, un-aesthetic office, etc., workers will find it difficult to remain in their offices to discharge their responsibilities thereby lowering the rate of productivity. It is for this reason that Lewy (1991) states that the facilities in the office "must be adequate and appropriate for specific jobs and must be fitted for individual workers". Workers must be adequately trained on how to use the facilities and equipment in their offices. At the same time, sufficient allocation of resources must be made for the routine maintenance of the facilities to avoid breakdown and mal-functioning which may affect the productivity of the employee. Gerber et al. (1998) stated that the availability of suitable facilities, appliances and equipment facilitates the productivity of an employer.

Studies have shown that the characteristics of an office environment have a far-reaching effect on the attitude, behavior, perceptions, and the overall productivity of workers (Becker, 2002). In a study of Dole and Schroeder (2001), Isa and Yusoff (2015) on "the impact of various factors on the personality, job satisfaction and turnover intentions of professional accountants" found that employees who are satisfied with the physical work environment in terms of facilities stay longer at work and produces better work outcomes (Becker, 1981). It can be inferred that employee satisfaction is a significant factor in measuring the success of an organization such as the university.

Studies on the ambient and general characteristic of the office environments such as the level of noise, lighting (artificial and natural), temperature, humidity, windows, tables, shelves, floor, roof, etc show that such facilities and elements in the office environment have a great influence on employees ' attitudes, perception, behaviors, commitment, satisfaction and general performance (Humphries, 2005). Similarly, Leaman \& Bordass (2005) observed that "staff members who are not satisfied with the design, temperature, size, water, lightning quality, and noise situation in their offices often complain of lack of concentration to their duties" (Karasek \& Theorell, 1990). Also, office facilities in particular and general workplace environments have a significant influence on occupants' well-being, staff satisfaction and work productivity. Also, studies show that satisfaction with the physical working environment is directly related to job satisfaction and higher productivity Veitch et al., 2007; Mbazor et al., 2018).

The design and installation of office facilities differ from region to region. For instance, the Dutch office design is quite different from the office designs in many other countries (Van Meel, 2000). The author observed that "most of the Dutch offices are low or mid-rise buildings, the floor depth is limited and the majority of workstations are within the vicinity of a window". Van Meel (2000) further added that "there are little open-plan offices in the
Netherlands since office landscapes were strongly rejected in the mid-1970s and organizations accommodated their employees in individual or shared rooms rather than in-office landscapes". The study also asserts that "from the 1990s many Dutch organizations started changing their office layouts from a cellular structure with individual and small shared rooms to combi offices and flex offices". Even though some studies have identified the impacts of the office environment on organizational staffs' job attitude, satisfaction, perception, behavior as having an indirect effect on their concentration and productivity, other studies have not been able to establish the degree of influence office facilities has on staff productivity in the university environment.

A fundamental aspect of the workplace environment that contributes to such employee behavior is the layout of office space. Conventional workplace designs tend to provide closed private offices for employees (Edem et al., 2017). In contrast, the more contemporary open-plan design is characterized by an absence of floor to ceiling walls and internal boundaries, as illustrated by cubicles or partitioned workspaces (Veitch et al. 2007). Due to lower costs and convenience, the concept of open-plan office use continues to increase. Open-plan designs refer to offices with individual workstations placed within an open space; sometimes divided by panels, but also include conventional shared offices with several workers in an office space (Dilani, 2004). When introduced, open office plans were presumed to provide an environment that would increase work efficiency and facilitate communication, while reducing construction and equipment costs.

Meanwhile, proponents of the open-plan office suggest that the open plan creates flexible space, allowing for a reduction in set-up and renovation times (Milton et al. 2000). It also enables the accommodation of greater numbers of employees in reduced amounts of space. As a result the total office space required is reduced and organizations save on air conditioning, maintenance and building costs. Supporters of the open-plan design also claim that the design facilitates communication and increases interaction between employees, and as a result, improves employees'satisfaction, boost morale and productivity (Veitch \& Gifford, 1996). Indeed, some evidence exists to support these positive effects. Openplan offices have led to increased communication among co-workers, higher aesthetic judgments, and more group sociability than the conventional designs (Chandrasekar, 2011).

Also, Fassoulis and Alexopoulos (2015) in a study on the relationship between workplace satisfaction and productivity at the University of Athens found that workers are not satisfied with their office environment, and this dissatisfaction indirectly affected their work productivity in the university. The study traced the root of staff's dissatisfaction with the university's style of 
management which failed to encourage and support a new form of office for staff. Office facilities are meant to support the core objectives of universities which include teaching, learning and research. Therefore, issues about the provision, maintenance and management of such facilities are always of crucial interest to all stakeholders in the university system.

\subsection{An Overview of an Office and Office Facilities}

An office is described as a room or an area within an organization where employees perform administrative and ancillary work to support the realization of organizational goals and objectives (Abdul Ghafoor \& Tafique 2015). Every organization usually maintains an office space where it has a presence, even if the presence is for storage of grains or a full established presence like a university, agency or department, etc. From the various views expressed, it can be inferred that an office is any location where an employee carries out his/her official responsibilities.

The office is important for the growth and success of an organization. Hence, Taylor (2001) stated that the primary purpose of an office environment is to support workers in the performance of their prescribed responsibilities. Therefore, for an office to fulfill its purpose, it must maintain adequate space. Workspace in an office is used for routine office activities such as reading, writing, researching and several other administrative and non-administrative activities.

Adams and Scott 2002 identified nine generic types of workspace in offices, each supporting different activities. The study noted that "in addition to individual cubicles, one can find meeting rooms, lounges, and spaces for support activities, such as photocopying and filing". While offices can be built or set in any location and almost any building, some modern requirements for offices make this more difficult, such as requirements for light, networking, and security. Workers occupy areas that are set within an office building and normally are provided with chairs, desks, computers and other necessary tools and equipment necessary for effective discharge of their duties.

On the other hand, a facility can be said to be something designed, built and installed to aid in serving a specific function, affording a convenience of services such as transportation facilities, research facilities, educational facilities, etc. and It could also be defined as something that allows easy performance of an action, course of conduct Roelofsen (2002).
Similarly, Clements-Croome et al., 2008) stated that office surroundings such as ventilation, temperature, color, lighting and other factors can affect the behavior, attitude and conduct of an employee". The study further stated that these identified elements can either produce comfort or discomfort to the occupant, he noted that either of them affects the attitude, behavior and conduct of office or building occupant. The interior elements of an office such as lighting and decoration elements can affect employee attitude thereby influencing their productivity rates.

Some studies have shown that fluorescent lighting in an office increases the level of stress and causes hyperactivity more than an incandescent lighting. Also, Lackney (1994) observed in a study that students in classrooms where there are no windows had more negative attitudes than those who have access to the natural light. Suitable physical facilities in an office boost the employee's morale thereby improving their productivity Arokiasamy, 2013 \& Kruger and Dorigo 2008.

\section{RESEARCH METHODOLOGY}

The study was conducted at the Federal University of Technology Akure, Nigeria. Data for the study was administered through the use of questionnaires. The questionnaire was administered to 204 academic and non-academic staff from the eight (8) academic schools that are in the university. The study concentrated on academic faculties and consideration was not given to other staff in other units within the university. 180 of the sampled questionnaires representing $90 \%$ were retrieved and are found fit for analysis. The questionnaire consisted of arrays of questions addressing the issues of facilities in staff offices, their state of repair, level of satisfaction and relevance of the facilities to service delivery. The data were collated and analyzed using descriptive statistics on a 5 point Linkert scale and presented as follows:

\section{ANALYSIS AND DISCUSSION OF RESULTS}

Table 1 illustrates the distribution and the retrieval of the questionnaires by respondents in the above study area. A total of 204 questionnaires were administered accordingly to the staff and 184 questionnaires were returned representing $90.2 \%$ and were considered fit for analysis. The rate of response shows a positive response, an indication that the data are reliable for analysis.

Table 1. The distribution and retrieval rate of questionnaire amongst respondent (Mbazor, 2019)

\begin{tabular}{|l|l|l|l|}
\hline RESPONDENTS & $\begin{array}{l}\text { No of questionnaire } \\
\text { administered }\end{array}$ & $\begin{array}{l}\text { No of questionnaire } \\
\text { retrieved }\end{array}$ & $\begin{array}{l}\text { Percentage (\%) of questionnaire } \\
\text { retrieved }\end{array}$ \\
\hline Total & $\mathbf{2 0 4}$ & $\mathbf{1 8 4}$ & $\mathbf{9 0 . 2}$ \\
\hline
\end{tabular}


Table 2. shows the socio-economic information of the respondents (Mbazor, 2019)

\begin{tabular}{|l|l|l|}
\hline $\begin{array}{l}\text { General } \\
\text { information of } \\
\text { the respondent }\end{array}$ & Frequency & Percentage \\
\hline $\begin{array}{l}\text { Age of } \\
\text { respondents }\end{array}$ & & \\
\hline $20-30$ & 23 & 12.5 \\
\hline $31-40$ & 107 & 58.2 \\
\hline $41-50$ above & 54 & 29.3 \\
\hline Total & 184 & 100.0 \\
\hline $\begin{array}{l}\text { Sex of the } \\
\text { respondent }\end{array}$ & & \\
\hline Male & 121 & 65.8 \\
\hline Female & 63 & 34.2 \\
\hline Total & $\mathbf{1 8 4}$ & $\mathbf{1 0 0 . 0}$ \\
\hline Marital status & & 90.2 \\
\hline Married & 167 & 9.2 \\
\hline Single & 17 & $\mathbf{1 0 0 . 0}$ \\
\hline Total & $\mathbf{1 8 4}$ & \\
\hline Job Cadre & & 7.1 \\
\hline $\begin{array}{l}\text { Graduate assistant } \\
\text { / Assistant } \\
\text { lecturer }\end{array}$ & 13 & 76.1 \\
\hline $\begin{array}{l}\text { Lecturer II / } \\
\text { lecturer I / Senior } \\
\text { Lecturer }\end{array}$ & 140 & 1.6 \\
\hline Reader / Professor & 3 & 15.2 \\
\hline $\begin{array}{l}\text { Non-academic } \\
\text { staff }\end{array}$ & 28 & $\mathbf{1 0 0 . 0}$ \\
\hline Total & $\mathbf{1 8 4}$ & \\
\hline $\begin{array}{l}\text { Occupation of } \\
\text { office status }\end{array}$ & 161 & \\
\hline Yes & & \\
\hline & & \\
\hline
\end{tabular}

\begin{tabular}{|l|l|l|}
\hline No & 23 & 12.5 \\
\hline Total & $\mathbf{1 8 4}$ & $\mathbf{1 0 0 . 0}$ \\
\hline $\begin{array}{l}\text { Length of stay in } \\
\text { the office }\end{array}$ & & \\
\hline $1-5$ years & 4 & 2.2 \\
\hline 6-10 years & 65 & 35.3 \\
\hline $11-15$ years & 102 & 55.4 \\
\hline $\begin{array}{l}16-20 \text { years and } \\
\text { above }\end{array}$ & 13 & 7.1 \\
\hline Total & $\mathbf{1 8 4}$ & $\mathbf{1 0 0 . 0}$ \\
\hline
\end{tabular}

From table 2 above, $65.8 \%$ of the population is male and $34.2 \%$ are female, this indicates that most of the respondents are male with $90.2 \%$ married and $9.8 \%$ single, academic staff constitute $84.8 \%$ while nonacademic staff was $15.2 \%$. On the issue of office ownership (status), $87.5 \%$ of the sampled staff has offices attached to them personally or shared with their colleagues, while $12.5 \%$ of those sampled does not have offices attached to them. On the length of stay in the offices, $2.2 \%, 35.5 \%, 55.4 \%$ and $7.1 \%$ of the staff have occupied their respective offices between 1-5 years, 6-10 years, 11-15 years, 16-20 years and above respectively. On the age distribution of the respondents, $12.5 \%, 58.2 \%$ and $29.3 \%$ have their ages ranging from 20-30, 31-40 and 41-50 and above respectively.

The implication of this is that there are mature men and female staff who are experienced, with personal or shared offices, and have spent a reasonable number of years in the university and as such is well qualified to give accurate and reliable responses for the study.

Table 3. The identified facilities available in the staff offices at the federal university of Technology Akure (Mbazor, 2019)

\begin{tabular}{|l|l|l|l|l|}
\hline Facilities & Yes & No & Undecided & Total \\
\hline Office Table & $122(66.3 \%)$ & $34(18.5 \%)$ & $28(15.2 \%)$ & $184(100 \%)$ \\
\hline Office Chairs & $122(66.3 \%)$ & $34(18.5 \%)$ & $28(15.2 \%)$ & $184(100 \%)$ \\
\hline Office Cabinet & $22(12 \%)$ & $162(88 \%)$ & $0(00 \%)$ & $184(100 \%)$ \\
\hline Sofa & $30(16.3 \%)$ & $116(63 \%)$ & $38(20.7 \%)$ & $184(100 \%)$ \\
\hline Visitors' chair & $122(66.3 \%)$ & $2(1.1 \%)$ & $60(32.6 \%)$ & $184(100 \%)$ \\
\hline Book Shelf & $95(51.6 \%)$ & $35(19 \%)$ & $54(29.3 \%)$ & $184(100 \%)$ \\
\hline Printer & $117(63.6 \%)$ & $34(18.5 \%)$ & $33(17.9 \%)$ & $184(100 \%)$ \\
\hline Wi-Fi & $179(97.3 \%)$ & $5(2.7 \%)$ & $0(00 \%)$ & $184(100 \%)$ \\
\hline Computer & $130(70.7 \%)$ & $20(10.9 \%)$ & $34(18.5 \%)$ & $184(100 \%)$ \\
\hline Refrigerator & $128(69.6 \%)$ & $37(20.1 \%)$ & $19(10.3 \%)$ & $184(100 \%)$ \\
\hline Water Dispenser & $39(21.2 \%)$ & $130(70.7 \%)$ & $15(8.2 \%)$ & $184(100 \%)$ \\
\hline Florescent tube & $184(100 \%)$ & $0(00 \%)$ & $0(00 \%)$ & $184(100 \%)$ \\
\hline Air Conditioner & $111(60.3 \%)$ & $46(25 \%)$ & $27(14.7 \%)$ & $184(100 \%)$ \\
\hline Rug/Carpet & $8(4.3 \%)$ & $50(27.2 \%)$ & $126(68.5 \%)$ & $184(100 \%)$ \\
\hline Conveniences & $94(51.1 \%)$ & $4(2.2 \%)$ & $86(46.7 \%)$ & $184(100 \%)$ \\
\hline Window Blinds & $166(90.2 \%)$ & $5(2.7 \%)$ & $13(7.1 \%)$ & $184(100 \%)$ \\
\hline Extinguisher & $4(2.2 \%)$ & $170(92.4 \%)$ & $10(5.4 \%)$ & $184(100 \%)$ \\
\hline Waste bin & $114(62 \%)$ & $5(2.7 \%)$ & $64(35.3 \%)$ & $184(100 \%)$ \\
\hline
\end{tabular}

From table 3 as shown above, it is observed that the respondents agreed that all the facilities listed are available in their offices. The implication of this is that workers are provided with basic facilities to work with and this could enhance their productivity. 
Table 4. The condition of the office facilities at the federal university of Technology Akure, Nigeria (Mbazor, 2019).

\begin{tabular}{|l|l|l|l|l|l|l|l|}
\hline Facilities & Very good & Good & Fair & Poor & Very poor & MEAN & Rank \\
\hline Comp/Laptop & $86(46.7 \%$ & $44(23.9 \%$ & $20(10.9 \%$ & $26(14.1 \%$ & $8(4.3 \%)$ & 3.9457 & $1^{\text {st }}$ \\
\hline Waste bin & $72(39.1 \%$ & $32(17.4 \%$ & $72(39.1 \%$ & $8(4.3 \%)$ & $0(00 \%)$ & 3.9130 & $2^{\text {nd }}$ \\
\hline Refrigerator & $67(36.4 \%$ & $38(20.7 \%$ & $71(38.6 \%$ & $8(4.3 \%)$ & $0(00 \%)$ & 3.8913 & $3^{\text {rd }}$ \\
\hline Fan & $33(17.9 \%$ & $82(44.6 \%$ & $57(31 \%)$ & $6(3.3 \%)$ & $6(3.3 \%)$ & 3.7065 & $4^{\text {th }}$ \\
\hline Air Conditional & $35(19 \%)$ & $96(52.2 \%$ & $14(7.6 \%)$ & $38(20.7 \%$ & $1(0.5 \%)$ & 3.6848 & $5^{\text {th }}$ \\
\hline Office Table & $30(16.3 \%$ & $62(33.7 \%$ & $80(43.5 \%$ & $12(6.5 \%)$ & $0(00 \%)$ & 3.5978 & $6^{\text {th }}$ \\
\hline Florescent tube & $12(6.5)$ & $52(28.3 \%$ & $74(40.2 \%$ & $32(17.4 \%$ & $14(7.6 \%)$ & 3.0870 & $7^{\text {th }}$ \\
\hline Water Dispenser & $0(00 \%)$ & $71(38.6 \%$ & $35(19 \%)$ & $78(42.4 \%$ & $0(00 \%)$ & 2.9620 & $8^{\text {th }}$ \\
\hline Window Blinds & $0(00 \%)$ & $46(25 \%)$ & $96(52.2 \%$ & $30(16.3 \%$ & $12(6.5 \%)$ & 2.9565 & $90^{\text {th }}$ \\
\hline Wi-Fi & $0(00 \%)$ & $43(23.4 \%$ & $63(34.2 \%$ & $66(35.9 \%$ & $12(6.5 \%)$ & 2.7446 & $10^{\text {th }}$ \\
\hline Carpet & $18(9.8 \%)$ & $20(10.9 \%$ & $60(32.6 \%$ & $40(21.7 \%$ & $46(25 \%)$ & 2.5870 & $11^{\text {th }}$ \\
\hline Book Shelf & $0(00 \%)$ & $30(16.8 \%$ & $64(34.8 \%$ & $64(34.8 \%$ & $26(14.1 \%$ & 2.5326 & $12^{\text {th }}$ \\
\hline White board & $38(20.7$ & $27(14.7 \%$ & $9(4.9 \%)$ & $20(10.9 \%$ & $90(48.9 \%$ & 2.4728 & $13^{\text {th }}$ \\
\hline Sofa & $16(8.7 \%)$ & $20(10.9 \%$ & $55(29.9 \%)$ & $15(8.2 \%)$ & $78(42.4 \%)$ & 2.3533 & $14^{\text {th }}$ \\
\hline Fire Extinguisher & $9(4.9 \%)$ & $10(5.4 \%)$ & $22(12 \%)$ & $73(39.7 \%)$ & $70(38 \%)$ & 1.9946 & $15^{\text {th }}$ \\
\hline Conveniences & $0(00 \%)$ & $12(6.5 \%)$ & $28(15.2 \%)$ & $68(37 \%)$ & $76(41.3 \%)$ & 1.8696 & $16^{\text {th }}$ \\
\hline
\end{tabular}

Table 4 above shows the condition of facilities in the staff offices. Respondents were asked to comment on the condition of facilities in their office and their responses are as shown in table 4 above. The facilities are in varying conditions and are ranked by their weighted means. Computer/laptop system, waste bin and refrigerator ranked $1^{\text {st }}, 2^{\text {nd }}$, and $3^{\text {rd }}$ with a mean score value of 3.9457 , 3.9130 and 3.8913 respectively which indicates that those facilities are in a very good condition in the university. Whereas, fire extinguisher and conveniences rank $19^{\text {th }}$ and $20^{\text {th }}$ with a corresponding means score values of 1.9946 and 1.8696 respectively, indicating that the facilities are in a very poor condition. The implication of this is that staff members are working in a high-risk environment given that the conditions of fire extinguishers are very bad. The lives and property of staff members at the workplace are at a high risk in the event of a fire outbreak. The study further revealed that the conditions of the conveniences are also very bad. The implication, therefore, is that staff will naturally answer to the call of nature which may be far away from their duty post and may take a long period to return to work and thus affects productivity.

Table 5. The level of satisfaction derived by the staff from the various office facilities (Mbazor, 2019)

\begin{tabular}{|l|l|l|l|l|l|l|l|}
\hline Facilities & $\begin{array}{l}\text { Very } \\
\text { satisfied }\end{array}$ & Satisfied & Indifferent & dissatisfied & $\begin{array}{l}\text { very } \\
\text { dissatisfied }\end{array}$ & MEAN & Ranking \\
\hline Book shelf & $170(92.4)$ & $0(00 \%)$ & $14(7.6 \%)$ & $0(00 \%)$ & $0(00 \%)$ & 4.8478 & $1^{\text {st }}$ \\
\hline Waste bin & $66(35.9 \%)$ & $38(20.7 \%)$ & $72(39.1 \%)$ & $4(2.2 \%)$ & $4(2.2 \%)$ & 3.8587 & $2^{\text {nd }}$ \\
\hline Office Table & $90(48.9 \%)$ & $25(13.6 \%)$ & $16(8.7 \%)$ & $37(20.1 \%)$ & $16(8.7 \%)$ & 3.7391 & $3^{\text {rd }}$ \\
\hline Office Cabinet & $47(25.5 \%)$ & $51(27.7 \%)$ & $50(27.2 \%)$ & $10(5.4 \%)$ & $26(14.1 \%)$ & 3.4511 & $4^{\text {th }}$ \\
\hline Window Blinds & $77(41.8 \%)$ & $18(9.8 \%)$ & $32(17.4 \%)$ & $16(8.7 \%)$ & $41(22.3 \%)$ & 3.4022 & $5^{\text {th }}$ \\
\hline Comp. Laptop & $37(20.1 \%)$ & $37(20.1 \%)$ & $78(42.4 \%)$ & $16(8.7 \%)$ & $16(8.7 \%)$ & 3.3424 & $6^{\text {th }}$ \\
\hline Florescent tube & $39(21.2 \%)$ & $41(22.3 \%)$ & $58(31.5 \%)$ & $20(10.9 \%)$ & $26(14.1 \%)$ & 3.2554 & $7^{\text {th }}$ \\
\hline Ceiling Fan & $16(8.7 \%)$ & $58(31.5 \%)$ & $78(42.4 \%)$ & $16(8.7 \%)$ & $16(8.7 \%)$ & 3.2283 & $8^{\text {th }}$ \\
\hline Air Conditioner & $11(6 \%)$ & $56(30.4 \%)$ & $32(17.4 \%)$ & $85(46.2 \%)$ & $0(00 \%)$ & 2.962 & $9^{\text {th }}$ \\
\hline Refrigerator & $47(25.5 \%)$ & $23(12.5 \%)$ & $30(16.3 \%)$ & $20(10.9 \%)$ & $64(34.8 \%)$ & 2.8315 & $10 t^{\text {th }}$ \\
\hline Water dispenser & $39(21.2 \%)$ & $19(10.3 \%)$ & $25(13.6 \%)$ & $46(25 \%)$ & $55(29.9 \%)$ & 2.6793 & $11^{\text {th }}$ \\
\hline Wi-Fi & $16(8.7 \%)$ & $16(8.7 \%)$ & $37(20.1 \%)$ & $79(42.9 \%)$ & $36(19.6 \%)$ & 2.4402 & $12^{\text {th }}$ \\
\hline Extinguisher & $38(20.7 \%)$ & $14(7.6 \%)$ & $25(13.6 \%)$ & $17(9.2 \%)$ & $90(48.9 \%)$ & 2.4185 & $13^{\text {th }}$ \\
\hline Conveniences & $6(3.3 \%)$ & $47(25.5 \%)$ & $26(14.1 \%)$ & $37(20.1 \%)$ & $68(37 \%)$ & 2.3804 & $14^{\text {th }}$ \\
\hline Sofa & $0(00 \%)$ & $0(00 \%)$ & $50(27.2 \%)$ & $107(58.2 \%)$ & $27(14.7 \%)$ & 2.125 & $15^{\text {th }}$ \\
\hline
\end{tabular}

Table 5 above shows the respondent's level of satisfaction with the various office facilities provided by their employer. The results revealed that the respondents were very satisfied with bookshelf, waste bin and office table which have mean score values of $4.8478,3.8587$ and 3.7391 respectively. While on the other hand, the staffs were very dissatisfied with the internet; fireextinguisher; conveniences and sofa which have a means score value of less than 2.5. These findings imply that staff's productivity will be affected due to inadequate internet services and poor conveniences such as toilets and urinary. 
Table 6. shows the relevance of office facilities to the work productivity of the staff in the University (Mbazor, 2019).

\begin{tabular}{|l|l|l|l|l|l|l|l|}
\hline Facilities & highly relevant & Relevant & Neutral & irrelevant & Highly irrelevant & Mean & Ranking \\
\hline & & & & & & & \\
\hline Water & $42(22.8 \%)$ & $70(38 \%)$ & $56(30.4 \%)$ & $8(4.3 \%)$ & $8(4.3 \%)$ & 4.4783 & $1^{\text {st }}$ \\
\hline Toilet & $36(19.6 \%)$ & $80(43.5 \%)$ & $36(19.6 \%)$ & $24(13 \%)$ & $8(4.3 \%)$ & 4.3370 & $2^{\text {nd }}$ \\
\hline Electricity & $44(23.9 \%)$ & $56(30.4 \%)$ & $40(21.7 \%)$ & $40(21.7 \%)$ & $4(2.2 \%)$ & 4.2446 & $3^{\text {rd }}$ \\
\hline Wi-Fi & $56(30.4 \%)$ & $56(30.4 \%)$ & $58(31.5 \%)$ & $10(5.4 \%)$ & $4(2.2 \%)$ & 4.1902 & $4^{\text {th }}$ \\
\hline Int. Envt. & $74(40.2 \%)$ & $56(30.4 \%)$ & $38(20.7 \%)$ & $10(5.4 \%)$ & $6(3.3 \%)$ & 4.0924 & $5^{\text {th }}$ \\
\hline Computer & $74(40.2 \%)$ & $56(30.4 \%)$ & $30(16.3 \%)$ & $20(10.9 \%)$ & $4(2.2 \%)$ & 4.0870 & $6^{\text {th }}$ \\
\hline Ext. Envt. & $40(21.7 \%)$ & $79(42.9 \%)$ & $38(20.7 \%)$ & $17(9.2 \%)$ & $10(5.4 \%)$ & 4.0870 & $6^{\text {th }}$ \\
\hline Air Condition & $35(19 \%)$ & $56(30.4 \%)$ & $75(40.8 \%)$ & $8(4.3 \%)$ & $10(5.4 \%)$ & 4.0326 & $8^{\text {th }}$ \\
\hline Refrigerator & $44(23.9 \%)$ & $68(3.7 \%)$ & $56(30.4 \%)$ & $8(4.3 \%)$ & $8(4.3 \%)$ & 3.9837 & $9^{\text {th }}$ \\
\hline Office table & $74(40.2 \%)$ & $72(39.1 \%)$ & $20(10.9 \%)$ & $18(9.8 \%)$ & $0(00 \%)$ & 3.9076 & $10^{\text {th }}$ \\
\hline Office cabinet & $20(10.9 \%)$ & $74(40.2 \%)$ & $74(40.2 \%)$ & $8(4.3 \%)$ & $8(4.3 \%)$ & 3.6033 & $11^{\text {th }}$ \\
\hline Book shelf & $34(18.5 \%)$ & $74(40.2 \%)$ & $56(30.4 \% 0$ & $12(6.5 \%)$ & $8(4.3 \%)$ & 2.5217 & $14^{\text {th }}$ \\
\hline Printer/Scan & $12(6.5 \%)$ & $12(6.5 \%)$ & $75(40.8 \%)$ & $52(28.3 \%)$ & $33(17.9 \%)$ & 2.3207 & $15^{\text {th }}$ \\
\hline Photocopier & $64(34.8 \%)$ & $80(43.5 \%)$ & $24(13 \%)$ & $8(4.3 \%)$ & $8(4.3 \%)$ & 2.1304 & $16^{\text {th }}$ \\
\hline Daylight & $36(19.6 \%)$ & $82(44.6 \%)$ & $14(7.6 \%)$ & $28(15.2 \%)$ & $24(13 \%)$ & 1.8859 & $17^{\text {th }}$ \\
\hline
\end{tabular}

Table 6 above shows the relevance of office facilities to service delivery at the Federal University of Technology Akure, Nigeria. Findings revealed that water, toilet facility, electricity and Wi-Fi are highly relevant as they have a mean score value of above 4 points which proves how highly relevant they are to staff productivity.

On the other hand, daylight has a mean score value of 1.8859 which shows that it is not too relevant for staff productivity. This further shows that workers can still be work efficient with the aid of artificial light such as fluorescent light. This finding implies that if organizations can provide adequate water, electricity, toilet and internet facilities at the workplace, there will be a corresponding increase in the rate of workers' productivity.

\section{FINDINGS}

The study was on the influence of office facilities in staff productivity at the Federal University of Technology, Akure Nigeria. The study revealed that the staff offices have basic facilities such as office tables, chairs, bookshelf, scanner, internet facilities, computer, ceiling fan, refrigerator, waste bin, etc. Secondly, the conditions of fire prevention facilities such as fire extinguisher installed for workers are not functional; the same applies to the toilet facilities. Thirdly, the finding further revealed that the staffs are very dissatisfied with the condition of conveniences and the state of the sofa in the offices. Finally, findings revealed that the most relevant facilities that influence staff productivity are in the study area are water, electricity, and Wi-Fi.

\section{RECOMMENDATION}

Based on the findings of this study the following recommendations are made:

- Adequate and modern office facilities should be provided to the staff of universities to aid their service delivery and enhanced work productivity.

- Both the internal and external environment of staff offices should constantly wear aesthetic look through continuous decoration and improvement.

- Universities should provide adequate water supply, build good conveniences (toilet), provide high speed internet facility, and install modern and easy to operate fire extinguisher in the staff offices.

- A good and comfortable sofa should be provided in the staff offices. This will enable staff to relax comfortably and take a rest doing break time.

\section{CONCLUSION}

The study concludes that the provision of decent work environment and adequate facilities in staff offices for university workers should be the primary objective of the every university management. University staffs' job satisfaction is directly related to the desire to stay, and the retention of the staff is fundamental for the advancement of research and development of a nation. The findings of this study have shown the influence of office facilities on staff productivity and service delivery and recommended that serious efforts should be made towards the provision and improvement of the office facilities and the internal and external office environment.

Good office environment internally and externally, adequate provision of facilities will boost the morale and performances of employees if sufficiently provided. If an office environment is neat, noiseless, properly arranged well lighted and ventilated, employees will feel satisfied and will be motivated to work diligently. Providing a decent physical working environment with all basic facilities inspires workers to spend a longer time in their offices. They will respond emotionally better if there is a provision of a well-arranged, sizeable and aesthetic office. It will further curb the issue of lateness, 
absenteeism, closing before time and nonchalant attitude as occasionally displayed by workers.

\section{References:}

Abdul Ghafoor, A. and Tafique, T. (2015). Impact of working environment on employee's productivity: A case studyof Banks and Insurance Companies in Pakistan. European Journal of Business and Management, 7(1), pp. $145-157$

Becker F (2002) Improving organizational performance by exploiting workplace flexibility. J Faculty Manage, 1, 154162.

Becker FO (1981). Workspace creating environments in an organization. New York: Praeger

Arokiasamy, A. R. A. (2013). A study on employee satisfaction perspectives in the hotel industry in Malaysia. International Journal of Management and Strategy, 4(6), pp. 78-93

Calder J., (2007). High-performance workplace, Public Number 3: Work-Life, Woods Bagot, London.

Chandrasekar K (2011). Workplace environment and its impact on organizational performance in public sector organizations. IJECBS 1: 1-20.

Clements-Croome, D. J., Awbi, H. B., Bako-Biro, Z., Kochhar, N. and Williams, M. (2008). Ventilation rates in schools. Building and Environment, 43(3), pp. 362-367

De Been, I. and Beijer, M. (2014). The influence of office type on satisfaction and perceived productivity support, Journal of Facilities Management, 12(2), pp. 142-157.

Dilani A (2004) Design and health III: Health promotion through environmental design. IADH

Edem MJ, Akpan EU, Pepple NM (2017) Impact of Workplace Environment on Health Workers. Occup. Med Health Aff 5:261.

Gerber, P.P., Nel, P.S. \& Van Dyk, P.S. (1998). Human Resource Management. Johannesburg: Internal Thomson Publishing.

Griffiths, A. \& Cox, T. (1996). Work-related stress in nursing: Controlling the risk to health. Working Paper London/T/WP/1996. (Geneva, International Labour Office, 1996)

Hamid N.Z.A., Hassan N. (2015). The Relationship Between Workplace Environment and Job Performance in Selected Government Places in Shah Alam - Selangor, International review of management and business research, 4, pp. 845-851.

Hassanain, M.A., Sedky, A., Adamu Z.A and Saif, A. (2010). A framework for quality evaluation of universityhousing facilities. Journal of Building Appraisal, 5 (3), pp 213-221.

Humphries M (2005) Quantifying occupant comfort: Are combined indices of the indoor environment practicable? Building Research and Information. 33, 317-325

Kaplan, R.S., Norton, D.P. (1996). The balanced scorecard: translating strategy into action, Harvard BusinessSchool Press, Boston, MA.

Karasek R, Theorell T (1990) Healthy work: Stress, productivity and the reconstruction of working life.

Kruger, E. L., and Dorigo, A. L. (2008). Daylighting analysis in a public school in Curitiba, Brazil. Renewable Energy, 1(33), pp. 1695-1702

Leaman, A., \& Bordass, W. (2005). Productivity in Buildings: The Killer Variables. London: The Usable Buildings Trust

Lewy, R.M. (1991). Employees at Risk: Protecting the Health of the Health Care Worker. New York: Van Nostrand Reinhold

Luthans, F. (1998). Organizational Behaviour. The Effective Health Care Supervisor. 5th ed. London: Jones and Bartlett Publishers

Mbazor D.N., Ajayi M.A., and Ige V.O. (2018), Staff Satisfaction with Workplace Facilities in the School of Environmental Technology, Federal University of Technology, Akure, Nigeria, Nigerian Journal Environmental Sciences and Technology, 2 (1), 69 - 77.

Mike A (2010) Visual workplace: How you see the performance on the planet and in the office. InternationalJournal of Financial Trade 11, 250-260.

Milton DK, Glencross PM, Walters MD (2000). Risk of sick leave associated with outdoor air supply rate, humidification and occupant complaints. Indoor Air, 10, 212-221.

Noblet, A. (2003). Building health-promoting work settings: Identifying the relationships between work characteristics and occupational stress in Australia. Health Promotion International, 18(4), 351359 
Roelofsen, P. (2002). The impact of office environments on employee performance: The design of the workplace as a strategy for productivity enhancement. Journal of Facilities Management, 11(3), pp. 247-264.

Schabracq, M.J. (2003). What an Organisation can do about its employees' well-being and health: An Overview. In M.J. Schabracq, J.A.M Winnubste \& Cooper, C.L. (Eds) 2003. The handbook of work and health psychology 2nd ed. UK: Wiley.

Van Meel, J.J. (2000). The European office: Office design and national context, 010 publishers, Rotterdam, 2000

Veitch J, Gifford R (1996). Choice, perceived control and performance decrement in the physical environment. $J$ Envir Psych., 16, 269-276.

Veitch, J., Charles, K., Farley, M., \& Newsham, G. (2007). A model of satisfaction with open-plan office conditions: Cope field endings. Journal of Environmental Psychology, 177-189

Wilkins, K., Mcleod, F. \& Schields, M. (2007). Nurses' Work and Health: New Findings. Health Policy Research Bulletin, 13:17-20

\section{David Ngwoke Mbazor}

Department of Estate Management

Federal University of Technology,

Akure,

Nigeria

dnmbazor@futa.edu.ng 
Mbazor, Proceedings on Engineering Sciences, , Vol. 02, No. 4 (2020) 409-418, doi: 10.24874/PES02.04.008 